UDK 577.1 : 61

ISSN 1452-8258

J Med Biochem 41: 62-70, 2022

\title{
CUL4A ATTENUATES LPS-INDUCED ACUTE KIDNEY INJURY VIA BLOCKING NF-KB SIGNALING PATHWAY IN SEPSIS
}

\author{
CUL4A UBLAŽAVA LPS-INDUKOVANU AKUTNU INSUFICIJENCIJU BUBREGA \\ BLOKIRANJEM NF-KB SIGNALNOG PUTA U SLUČAJU SEPSE
}

\author{
Jing Zhao ${ }^{1}$, Qiuxia Duan ${ }^{2}$, Cuihong Dong ${ }^{3}$, Jing Cui ${ }^{4}$ \\ ${ }^{1}$ Department of Critical Care Medicine, Yantaishan Hospital, Yantai, China \\ 2Department of Critical Care Medicine, The Third People's Hospital of Qingdao, Qingdao, China \\ ${ }^{3}$ Shandong College of Traditional Chinese Medicine, Yantai, China \\ ${ }^{4}$ Department of Emergency, The Third People's Hospital of Qingdao, Qingdao, China
}

\begin{abstract}
Summary
Background: Acute kidney injury (AKI) is a common disease that can develop into end-stage kidney disease. Sepsis is one of the main causes of AKI. Currently, there is no satisfactory way to treat septic AKI. Therefore, we have shown the protective function of Cul4a in septic AKI and its molecular mechanism.

Methods: The cellular and animal models of septic AKI were established by using lipopolysaccharide (LPS). Western blot (WB) was employed to analyze Cul4a expression. RT-qPCR was employed to test the expression of Cul4a, SOD1, SOD2, GPX1, CAT, IL-6, TNF- $\alpha$, Bcl-2, IL$1 \beta$, Bax and KIM-1 mRNA. ELISA was performed to detect the contents of inflammatory factors and LDH. CCK-8 was utilized to detect cell viability. Flow cytometry was utilized to analyze the apoptosis. DHE-ROS kit was used to detect the content of ROS.

Results: Cul4a was down-regulated in cellular and animal models of septic AKI. Oxidative stress is obviously induced by LPS, as well as apoptosis and inflammation. However, these can be significantly inhibited by up-regulating Cul4a. Moreover, LPS induced the activation of the NF- $\mathrm{KB}$ pathway, which could also be inhibited by overexpression of Cul4a.

Conclusions: Cul4awas found to be a protective factor in septic AKI, which could inhibit LPS-induced oxidative stress, apoptosis and inflammation of HK-2 cells by inhibiting the NF-KB pathway.
\end{abstract}

Keywords: sepsis, AKI, Cul4a, oxidative stress, inflammation, apoptosis

\section{Kratak sadržaj}

Uvod: Akutna insuficijencija bubrega (AKI) je česta bolest koja može prerasti u kritičnu fazu oštećenja bubrega. Sepsa je jedan od glavnih uzroka AKI. Trenutno ne postoji zadovoljavajući način lečenja septičke akutne insficijencije bubrega. Stoga smo pokazali zaštitnu funkciju Cul4a kod septičke insuficijencije bubrega i njegov molekularni mehanizam.

Metode: Ćelijski i životinjski modeli septičke akutne insuficijencije bubrega su izazvani upotrebom lipopolisaharida (LPS). Za analizu ekspresije Cul4a korišćen je Vestern blot (WB). RT-qPCR je korišćen za ispitivanje ekspresije mRNA Cul4a, SOD1, SOD2, GPKS1, CAT, IL-6, TNF- $\alpha$, Bcl-2, IL1 $\beta$, Bax-a i KIM-1 mRNA. Izvršena je ELISA analiza za otkrivanje sadržaja upalnih faktora i LDH. Za utvrđivanje održivosti ćelija korišćen je CCK-8. Za analizu apoptoze korišćena je protočna citometrija. Za otkrivanje sadržaja ROS-a korišćen je DHE-ROS komplet.

Rezultati: Cul4a je snižen u ćelijskim i životinjskim modelima septičkog AKI. Oksidativni stres je očigledno izazivan LPS-om, kao i apoptoza i upala. Međutim, oni se mogu značajno inhibirati regulacijom Cul4a. Štaviše, LPS je indukovao aktivaciju NF-kB signalnog puta, što bi takođe moglo biti inhibirano prekomernom ekspresijom Cul4a.

Zaključak: Utvrđeno je da je Cul4a zaštitni faktor u slučajevima akutne septičke insuficijencije bubrega, što, inhibirajući NF- $\kappa B$ signalni put, može sprečiti oksidativni stres izazvan LPS-om, apoptozu i upalu ćelija HK-2.

Ključne reči: sepsa, $\mathrm{AKI}, \mathrm{Cul} 4 \mathrm{a}$, oksidativni stres, zapaljenje, apoptoza

Address for correspondence:

Jing Cui, MM

Department of Emergency, The Third People's

Hospital of Qingdao

29 Yongping Road, Qingdao, Shandong 266000, China

Phone: 86017806299663

e-mail: cuijing512@163.com 


\section{Introduction}

AKI refers to a syndrome in which a patient's renal function is significantly declined rapidly due to various causes, and a series of clinical symptoms occur, including increased serum creatinine $(\mathrm{Cr})$, decreased urine output, electrolyte disturbance, acidbase imbalance, etc. In severe cases, acute brain edema, acute heart failure, or even life-threatening may occur. Suffering from AKI can lead to increased demand for renal replacement therapy, increased risk of death, and more treatment costs, which will bring a heavy burden to patients and society (1-3). AKI could be induced by many factors, including sepsis, ischemia-reperfusion injury, and nephrotoxic drugs. A large clinical study showed that in critically ill patients, septic shock is the main factor in the onset of AKI, accounting for $47.5 \%$ of the total population (4)

Sepsis is a continuous and excessive inflammatory response and immunosuppression caused by pathogen invasion. It is an important factor for organ failure of the body and can lead to shock and even death of patients (5). Sepsis is a common clinical systemic critical illness. In critically ill patients, the fatality rate reaches $35 \%(6)$, which seriously threatens the life and health of patients (7). Studies found that sepsis patients had a $50 \%$ risk of developing AKI, and such patients have a poor prognosis and high mortality $(8,9)$. In clinical practice, the treatment of septic AKI is often implemented through strategies such as fluid replacement, diuretics and antibiotics. However, the fatality rate of septic AKI has not been significantly reduced (10). Therefore, exploring new sepsis AKI treatment drugs is of great significance for alleviating kidney damage and saving patients' lives and health.

Cullin4A (Cul4a) belongs to the E3 ligase ubiquitin family in the ubiquitin-proteasome system (UPS) and determines the substrate specificity of ubiquitination modification (11-13). Cul4a ubiquitin ligase has a wide range of substrates and acts a pivotal part in a series of biological processes such as signal transduction, transcription regulation, cell cycle regulation, maintenance of genome stability, and embryo development $(14,15)$. At present, Cul4a has been extensively studied in various cancers $(16,17)$, but its function in kidney disease such as septic AKI is still unclear.

Here, we describe a new role of $\mathrm{Cul} 4 \mathrm{a}$, which is to inhibit inflammation and apoptosis mediated by oxidative stress in septic AKI. This will provide a potential new treatment for septic AKI.

\section{Materials and Methods}

\section{Rat septic AKI model}

Ten male Sprague-Dawley (SD) rats (Shanghai Experimental Animal Center of Chinese Academy of
Sciences) were raised in an SPF environment. The breeding room has a temperature of $22-25^{\circ} \mathrm{C}$ and a humidity of about $50 \%$. LPS ( $5 \mathrm{mg} / \mathrm{kg}$ ) was injected intraperitoneally to establish a septic AKI model.

\section{Cell treatment}

HK-2 cells, human renal cortex proximal convoluted tubule epithelial cell line, were purchased from Yaji Biotechnology Co., Ltd (Shanghai, China). The cells were cultured in a culture medium composed of DMEM/F-12 (Gibco, Rockville, MD, USA) and 10\% FBS (Gibco, Rockville, USA) at $37{ }^{\circ} \mathrm{C}$ with $5 \% \mathrm{CO}_{2}$. The medium needs to be changed every 24 hours. $500 \mathrm{ng} / \mathrm{mL}$ LPS was used to induce cell damage.

The Cul4a overexpression plasmids (Sangon Biotech, Shanghai, China) was transfected into HK-2 cells using Lipofectamine ${ }^{\mathrm{TM}} 3000$ in accordance with the instructions.

\section{Western blot}

Radioimmunoprecipitation assay lysis buffer (Beyotime, Shanghai, China) was used to extract the total protein in HK-2 cells. The concentration was examined by the BCA method. After incubation with the loading buffer, the same amount of protein (30 $\mu \mathrm{g})$ from each group was added into SDS-PAGE. The voltage was set to 120 volts. When the protein is sufficiently separated, it is transferred to the PVDF membrane. The current was set to $300 \mathrm{~mA}$. After the membranes were blocked by QuickBlock ${ }^{T M}$ Blocking Buffer (Beyotime, Shanghai, China), primary antibodies (Cul4a, Abcam, Cambridge, MA, USA, Rabbit,

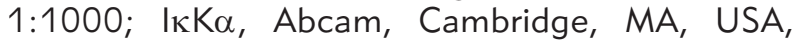

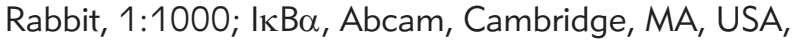
Rabbit, 1:1000; GAPDH, Abcam, Cambridge, MA, USA, Rabbit, 1:1000) were added and incubated at $4{ }^{\circ} \mathrm{C}$. The next day, the secondary antibody was used to incubate the membranes. The electrochemiluminescence (ECL) developer was added dropwise to develop imaging, and the grey value was semi-quantitatively analyzed according to Image J software.

\section{$R T$-qPCR analysis}

The TRlzol reagent (Invitrogen, Carlsbad, CA, USA) was used to extract total RNA in HK-2 cells following the protocols. The complementary deoxyribose nucleic acid (cDNA)was synthesized using Real Master Mix (Bio-Rad, Hercules, CA, USA). RT-qPCR was performed using the Prism 7900 System. GAPDH was utilized to normalize the expression of mRNAs. All the primers were listed in Table I. 
Table I Real-time PCR primers.

\begin{tabular}{|l|c|c|}
\hline Gene name & Forward $\left(5^{\prime}>3^{\prime}\right)$ & Reverse $\left(5^{\prime}>3^{\prime}\right)$ \\
\hline Cul4a & CAAGACAGGGAGGTTCCA & TCTCCACACAGGCAATCA \\
TNF- $\alpha$ & AGGCACTCCCCCAAAAGATG & CCACTTGGTGGTTTGTGAGTG \\
IL-1 $\beta$ & ATGCCACCTTTTGACAGTGATG & GAGGTCCACGGGAAAGACA \\
IL-6 & GCCTTCTTGGGACTGATGCT & CTGCAAGTGCATCATCGTTGT \\
SOD1 & CAATGTGGCTGCTGGAA & TGATGGAATGCTCTCCTGA \\
SOD2 & GCCGTGTTCTGAGGAGAG & GTCGTAAGGCAGGTCAGG \\
GPX1 & TTGAGAAGTGCGAGGTGAA & TCCGCAGGAAGGTAAAGAG \\
CAT & TGGTTTTCACCGACGAG & TTTGCCTTGGAGTATCTGG \\
Bcl-2 & GACTGAGTACCTGAACCGGCATC & CTGAGCAGCGTCTTCAGAGACA \\
Bax & CAGTTGAAGTTGCCATCAGC & CAGTTGAAGTTACCATCAGC \\
IKK $\alpha$ & AAACCAGAAAATTGTTGTGGACT & ATCGAATCCCAGACCCTATATCAC \\
IKB $\alpha$ & TAAGCAAAATCCTGACCTGGTGT & GCTCGTCCTCTGTGAACTCC \\
GAPDH & ACAACTTTGGTATCGTGGAAGG & GCCATCACGCCACAGTTTC \\
\hline
\end{tabular}

RT-PCR, quantitative reverse-transcription polymerase chain reaction

\section{Determination of malondialdehyde (MDA)}

The level of MDA in the supernatant of HK-2 cells was examined by Lipid Peroxidation (MDA) Assay Kit (Abcam, Cambridge, MA, USA) according to the instructions.

\section{Determination of ROS production}

The contents of ROS in HK-2 cells was tested using DCFH-DA (MCE, Nanjing, China). The cells were incubated with DCFH-DA $(5 \mu \mathrm{mol} / \mathrm{L})$ for $30 \mathrm{~min}$ in the dark. Then the cells were collected by $0.05 \%$ trypsin-EDTA solution. After that, the cells were suspended in a fresh medium. Finally, the level of ROS was tested by a flow cytometer.

\section{Enzyme-linked immunosorbent assay (ELISA)}

The supernatant of HK-2 cells was collected. The contents of inflammatory cytokines (IL-6, IL-1 $\beta$, TNF- $\alpha$ ) and LDH were detected by commercial ELISA kits (Elabscience, Wuhan, China) following the protocols.

\section{Flow Cytometry}

The HK-2 cells were collected by trypsin and centrifugation. Then the cells were resuspended in a $200 \mu \mathrm{L}$ binding buffer. After that, $5 \mu \mathrm{L}$ Annexin V-FITc and $5 \mu \mathrm{L} \mathrm{Pl}$ were added into the binding buffer. Finally, 10 min later, the apoptosis rate was measured by a flow cytometer.

\section{TUNEL staining}

The apoptosis was examined by TUNEL staining with a TUNEL kit (Roche, USA) following the manufacturers' instructions. The nucleus was stained by DAPI. The images were observed by the inverted fluorescence microscope.

\section{Statistical analysis}

The measurement data were described as the mean \pm standard deviation (SD). All statistical analyses were performed by GraphPad Prism 8.0. One-way analysis of variance (ANOVA) or Student's t-test was used for comparison. Significance was accepted at $\mathrm{P}<0.05$.

\section{Results}

Cul4a was down-regulated in LPS-treated HK-2 cells

First, the expression of Cul4a in the LPS-treated HK-2 cells was detected through WB. Compared with the control group, Cul4a expression in HK-2 cells of the LPS group was significantly reduced (Figure $1 A$ ). At the same time, the level of Cul4a mRNA was also examined, and the result was consistent with the protein level (Figure 1B). In addition, we constructed the rat model of septic $\mathrm{AKI}$ and also detected Cul4a expression in the kidney. Cul4a expression in the LPS group was less than that in the sham group (Figure $1 C$ and D). To further study the function of Cul4a, we transfected the Cul4a overexpression plasmid into cells and verified the transfection efficiency of the plasmid from the protein and mRNA levels (Figure $1 E$ and $F)$. 


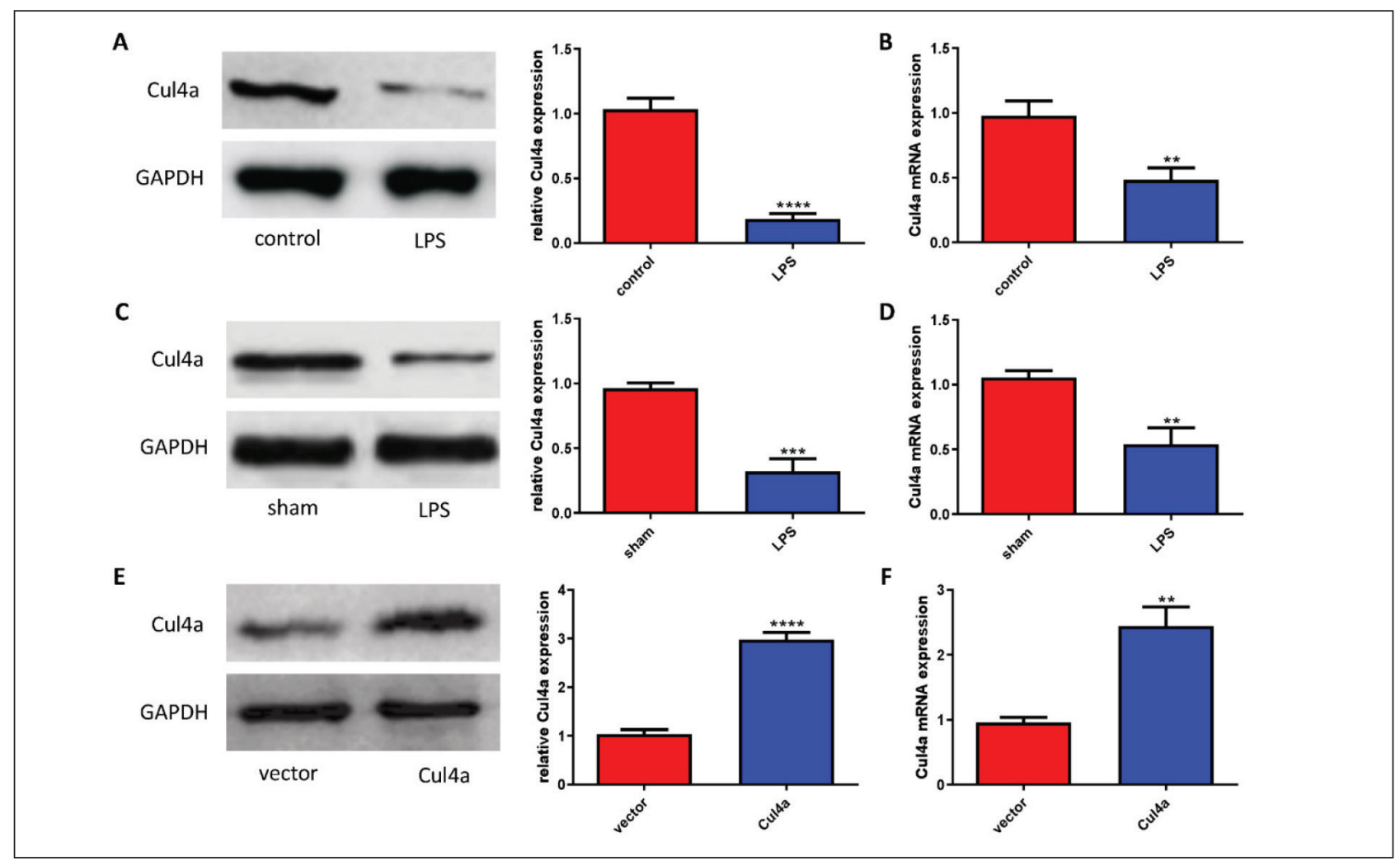

Figure 1 Cul4a was down-regulated in LPS-treated HK-2 cells. (A) Western blot showed the expression of Cul4a in HK-2 cells ("****" $\mathrm{p}<0.0001$ vs. control, $\mathrm{n}=3$ ). (B) Cul4a mRNA expression in HK-2 cells was detected by RT-PCR ("**" $p<0.01$ vs. control, $n=3)$. (C) Western blot showed the expression of Cul4a in kidney tissues of rats ("***" $p<0.001$ vs. sham, $n=3$ ). (D) Cul4a mRNA expression in kidney tissues of rats was detected by RT-PCR ("**" $p<0.01$ vs. sham, n=3). (E) The expression of Cul4a in HK-2 cells transfected with plasmids ("***" $p<0.001$ vs. control, $n=3$ ). (F) Cul4a mRNA expression in HK-2 cells transfected with plasmids was detected ("**" $\mathrm{p}<0.01$ vs. control, $\mathrm{n}=3$ ).

\section{Overexpression of Cul4a inhibited LPS-induced oxidative stress}

Through RT-qPCR, we detected the levels of SOD1, SOD2, GPX1, and CAT mRNA. Compared with the control group, the levels of those mRNA in the LPS group were remarkably reduced, suggesting that oxidative stress exists in septic AKI. However, compared with the LPS + vector group, the levels of those mRNA in the LPS +Cul4a group were significantly increased (Figure 2A 2D). The content of MDA in the cell supernatant was also detected. Overexpression of Cu14a notably inhibited the content of MDA induced by LPS (Figure 2E). In addition, Cul4a also markedly decreased the production of ROS induced by LPS (Figure 2F).

\section{Overexpression of Cul4a inhibited LPS-induced inflammation}

We also tested the inflammatory response in HK-2 cells. LPS obviously induced the production of inflammatory cytokines (IL-6, IL-1 $\beta$, TNF- $\alpha$ ) mRNA in HK-2 cells. While up-regulating Cul4a suppressed their expression (Figure 3A 3C). We also tested the contents of inflammatory cytokines in the cell super- natant. The content of inflammatory cytokines in the LPS +Cul4a group was markedly lower than those in the LPS+vector group (Figure 3D 3F).

\section{Overexpression of Cul4a inhibited LPS-induced apoptosis}

Through the CCK-8 assay, the cell viability was detected. The treatment of LPS significantly reduced the viability of HK-2 cells, but overexpression of Cul4a could reverse this (Figure 4A). Furthermore, overexpression of Cu14a can also reduce the release of $\mathrm{LDH}$ (Figure $4 \mathrm{~B}$ ). We also tested the expression of KIM-1 mRNA and found that LPS can significantly induce the expression of $\mathrm{KIM}-1$, while Cul4a can reduce this (Figure 4C). The expression of apoptosisrelated genes was also detected. The level of $\mathrm{Bcl}-2$ mRNA in the LPS treatment group was significantly reduced, while the level of Bax was significantly increased. Overexpression of Cu4a can reverse the above results (Figure $4 D$ and $4 E$ ). In addition, the rate of apoptosis was tested through flow cytometry and TUNEL staining. The results suggested that overexpression of Cul4a can inhibit LPS-induced apoptosis of HK-2 cells (Figure 4F and 4G). 


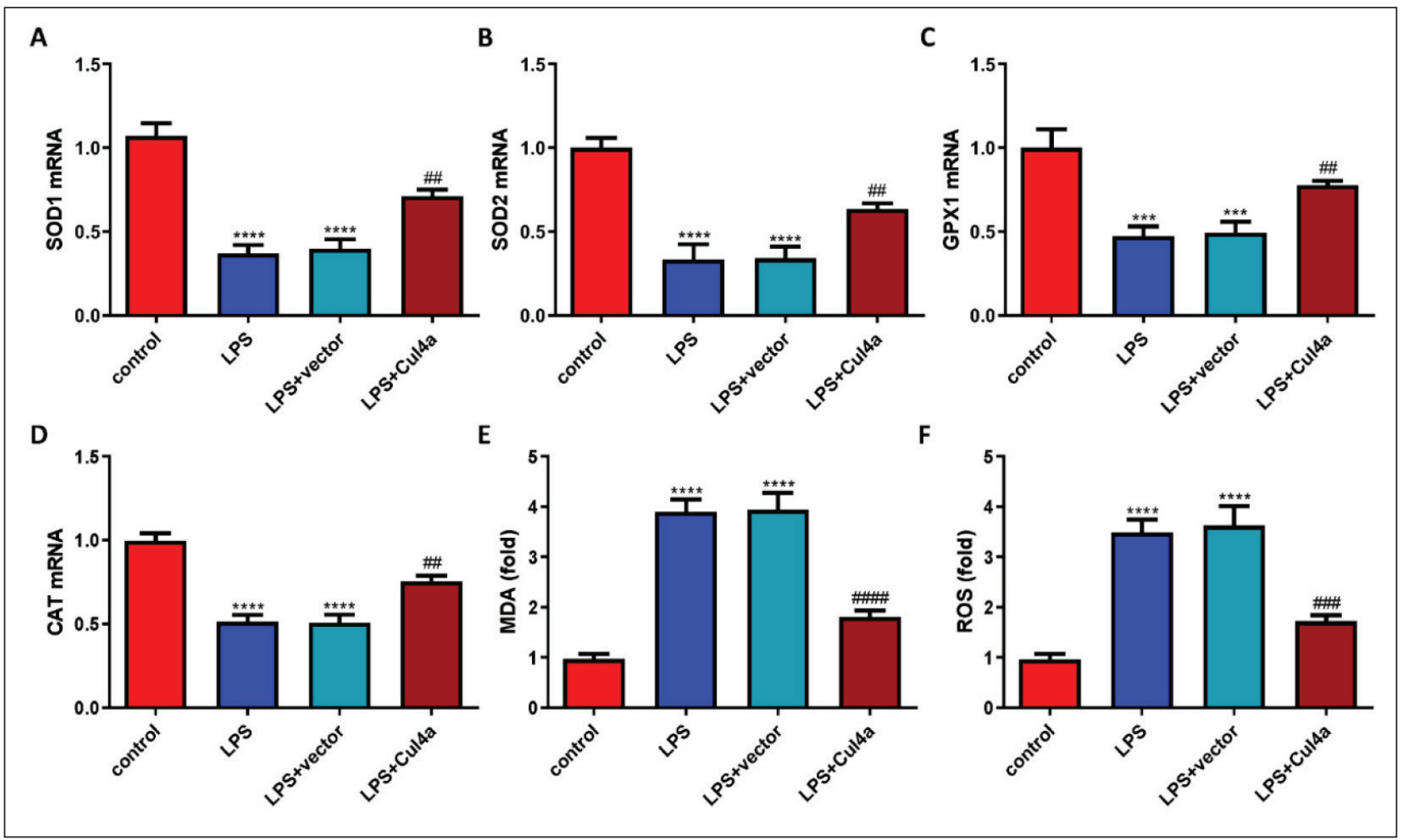

Figure 2 Overexpression of Cul4a inhibited LPS-induced oxidative stress of HK-2 cells. (A D) The levels of SOD1, SOD2, GPX1, CAT mRNA were detected through RT-qPCR("***" $p<0.001$ vs. control, "****" $p<0.0001$ vs. control, "\#\#" $p<0.01$ vs. LPS+vector, $n=3$ ). (E) The contents of MDA were detected ("****" $p<0.0001$ vs. control, "\#\#\#\#" $p<0.0001$ vs. LPS+vector, $n=3$ ). (F) The production of ROS in HK-2 cells was detected ("****" $p<0.0001$ vs. control, "\#\#\#" $p<0.001$ vs. LPS+vector, $n=3$ ).

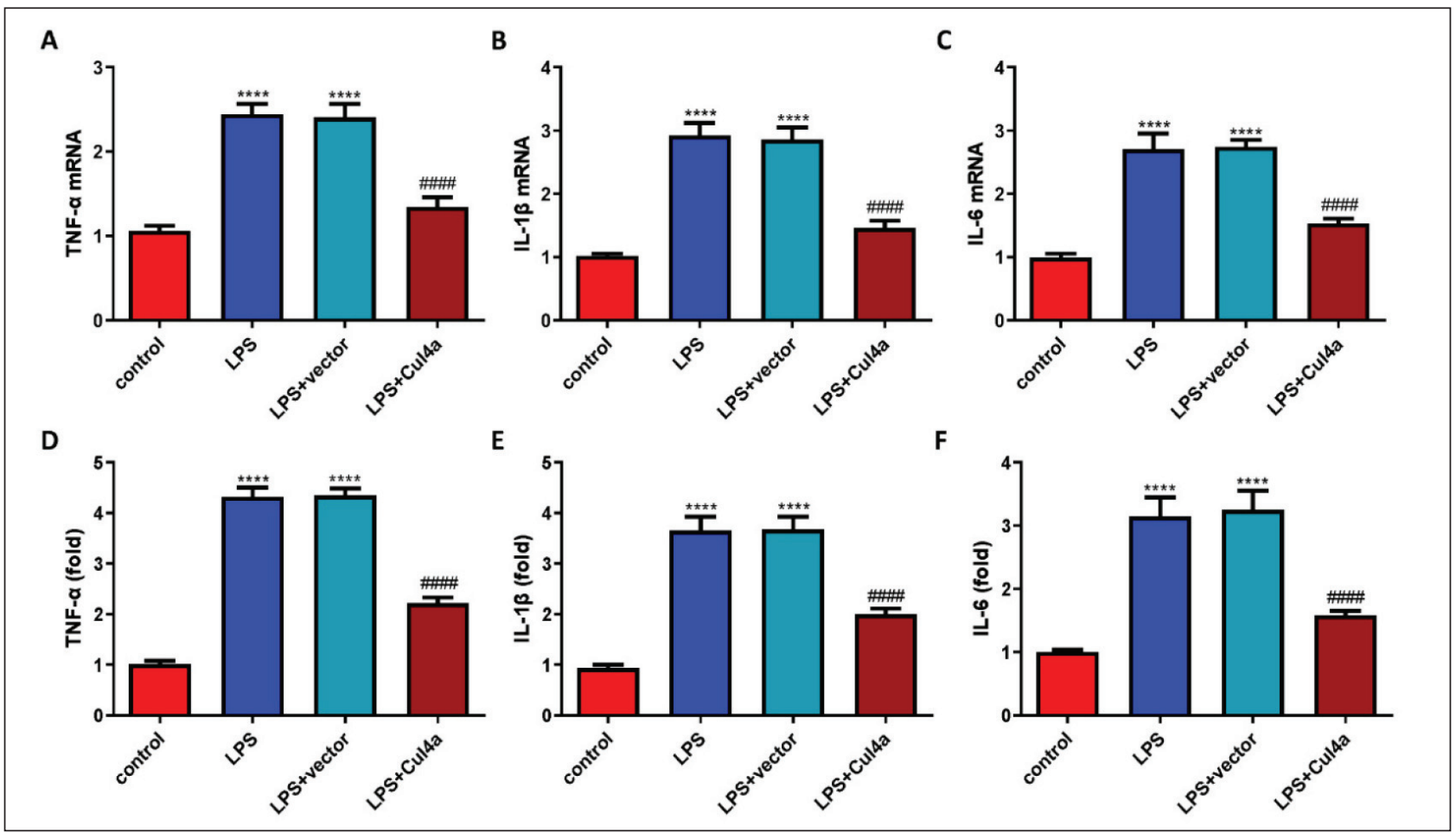

Figure 3 Overexpression of Cul4a inhibited LPS-induced inflammation of HK-2 cells. (A C) The levels of TNF- $\alpha$, IL-1 $1 \beta$, IL- 6 mRNA were detected through RT-qPCR ("****" $p<0.0001$ vs. control, "\#\#\#\#" $p<0.0001$ vs. LPS+vector, $n=3$ ). (D F) The contents of TNF- $\alpha$, IL-1 $\beta$, IL-6 in the supernatant were detected ("****" $p<0.0001$ vs. control, "\#\#\#\#" $p<0.0001$ vs. LPS +vector, $n=3$ ). 


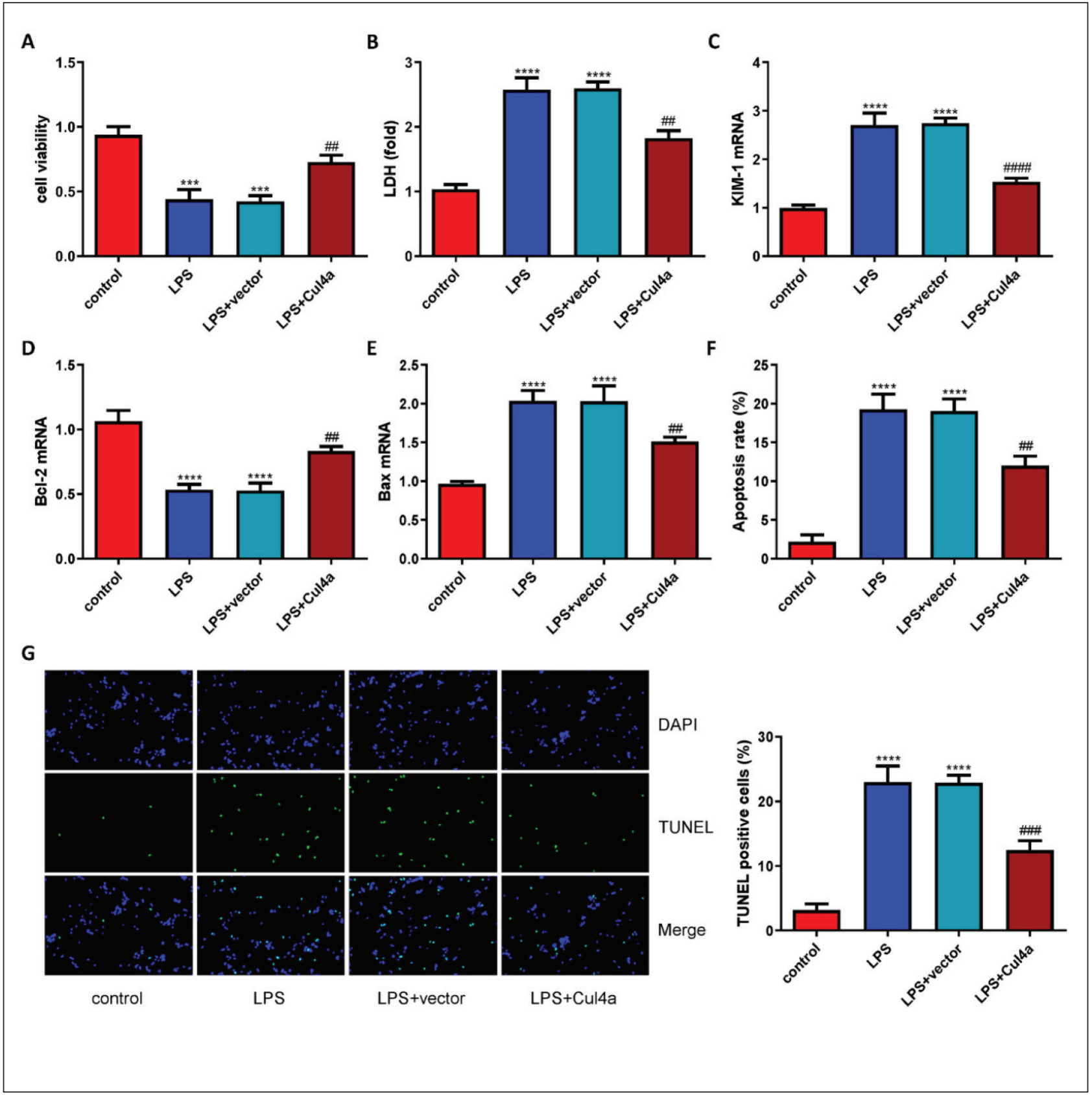

Figure 4 Overexpression of Cul4a inhibited LPS-induced apoptosis of HK-2 cells. (A) The viability of HK-2 cells was detected ("***" $p<0.001$ vs. control, "\#\#" $p<0.01$ vs. LPS + vector, $n=3$ ). (B) The contents of LDH in the supernatant were detected ("****" $\mathrm{p}<0.0001$ vs. control, "\#\#" $\mathrm{p}<0.01$ vs. LPS + vector, $\mathrm{n}=3$ ). (CDE) The levels of KIM-1, Bcl-2, Bax mRNA were detected ("****" $p<0.0001$ vs. control, "\#\#" $p<0.01$ vs. LPS+vector, "\#\#\#\#" $p<0.0001$ vs. LPS+vector, $n=3$ ). (F) The rate of apoptosis was detected by flow cytometry ("****" $\mathrm{p}<0.0001$ vs. control, "\#\#" $\mathrm{p}<0.01$ vs. LPS+vector, $\mathrm{n}=3$ ). (G) Results of TUNEL staining in each group $(200 \times)$ ("****" $p<0.0001$ vs. control, "\#\#\#" $p<0.001$ vs. LPS+vector, $n=3)$.

\section{Cul4a inhibited the NF- $\kappa B$ pathway}

Since the NF-KB pathway plays an important role in oxidative stress, inflammation, and apoptosis, we tested the marker proteins of this signalling pathway. The treatment of LPS significantly increased the expression of $I_{\kappa} K \alpha$ but decreased the expression of
$I_{\kappa} B \alpha$. However, overexpression of Cul4a significantly reversed their expression (Figure 5A). The expression of $I_{\kappa} K \alpha$ mRNA and $I_{\kappa} B \alpha$ mRNA was also detected, and the results were consistent with the previous results (Figure $5 B$ and $5 C$ ). 
A
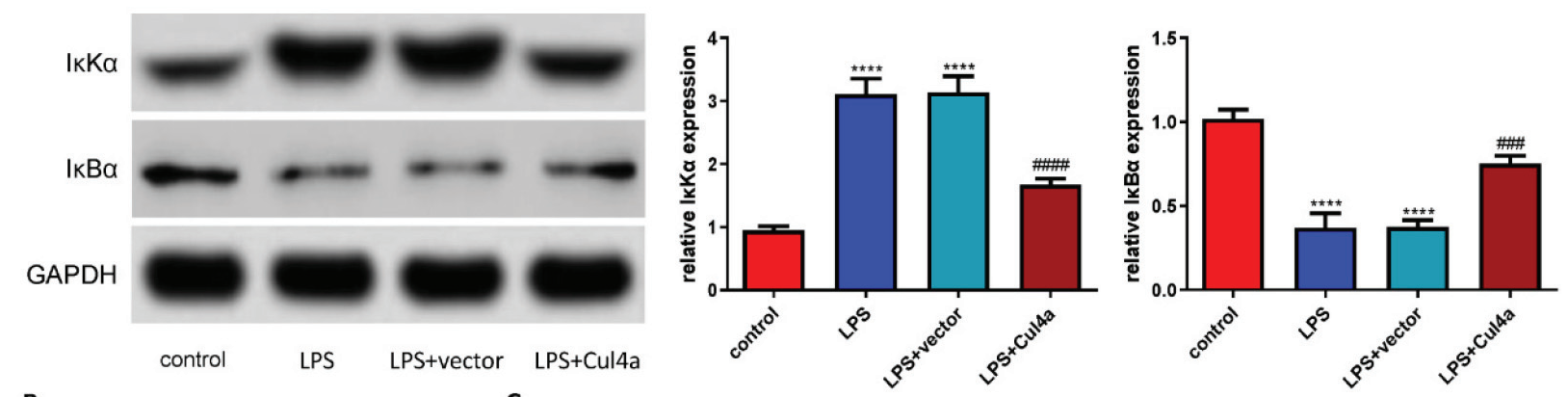

B

C
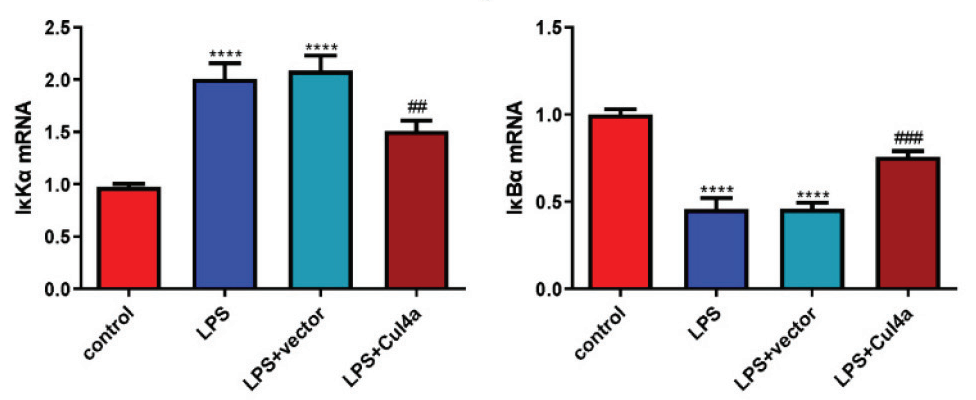

Figure 5 Cul4a inhibited the NF-KB signalling pathway. (A) The expression of IKKa and $\mid \kappa B \alpha$ was detected ("****" $\mathrm{p}<0.0001$ vs. control, "\#\#\#" $p<0.001$ vs. LPS+vector, "\#\#\#\#" $p<0.0001$ vs. LPS+vector, $n=3)$. (B and C) The levels of IkK $\alpha$ and lkB $\alpha$ mRNA were detected ("****" $p<0.0001$ vs. control, "\#\#" $p<0.01$ vs. LPS+vector, "\#\#\#" $p<0.001$ vs. LPS+vector, $n=3$ ).

\section{Discussion}

In this present study, we revealed the protective role of Cul4a in septic AKI. We have revealed for the first time that Cul4a is down-regulated in septic AKI. Overexpression of Cul4a can significantly inhibit oxidative stress, inflammation and apoptosis, thereby reducing septic $\mathrm{AKI}$. This protective effect was achieved at least in part by inhibiting the NF-кB signalling pathway.

The pathogenesis of $\mathrm{AKI}$ caused by sepsis is very complicated, which may be related to the increase of inflammatory factors, oxidative stress, and apoptosis $(18,19)$. Some scholars have suggested that inhibiting apoptosis, improving immune inflammation, and oxidative stress damage can help prevent AKI caused by sepsis (20). Apoptosis, especially renal tubular epithelial cell apoptosis, plays a key role in septic AKI. Sepsis may cause kidney cell apoptosis through endoplasmic reticulum stress, death receptor pathway, and mitochondrial pathway (21). In addition, sepsis can cause the body's systemic immune-inflammatory response and oxidative stress damage. Inflammation and oxidative stress can damage the glomeruli and renal tubules, leading to kidney damage, and, ultimately, renal insufficiency (22). Inflammatory factors such as IL- 6 and TNF- $\alpha$ and oxidative stress indicators such as SOD can be used as early diagnostic markers for $A K I$ caused by sepsis, and these markers have important values for judging the prognosis of the disease. Many studies have shown that inhibiting inflammatory factors and oxidative stress can help improve septic AKI. Chen et al. (23) proved that hydrogen sulfide could reduce septic AKI by inhibiting inflammation and oxidative stress. Rutin has also been shown to alleviate septic AKI in mice by inhibiting oxidative stress, inflammation, and apoptosis in the kidney (24).

$N F-\kappa B$ is a nuclear transcription factor involved in inflammation, oxidative stress and apoptosis (25, 26). Studies have found that the expression of NF-кB in the kidney tissue of septic $A K I$ rats increases. When $\mathrm{NF}-\kappa \mathrm{B}$ translocates to the nucleus, it can activate the downstream inflammatory factors and oxidative stress indicators such as SOD, etc., thereby promoting the aggravation of inflammatory response and oxidative stress damage and aggravating kidney damage. And inhibition of the NF- $\kappa$ B signalling pathway could reduce renal inflammation, oxidative stress, and apoptosis, thereby reducing renal injury.

Our study demonstrates the regulatory role of Cul4a in septic AKI. Overexpression of Cul4a can remarkably inhibit LPS-induced oxidative stress and inhibit the production of inflammatory factors and apoptosis of HK-2 cells. The protective effect of Cul4a is at least partially achieved by inhibiting the $\mathrm{NF}-\kappa \mathrm{B}$ pathway. 


\section{Conclusion}

To sum up, Cul4a was found to be a protective factor in septic AKI, and overexpression of Cul4a could inhibit LPS-induced oxidative stress, inflammation, and apoptosis of HK-2 cells by inhibiting the NF-кB pathway.

\section{References}

1. Li PK, Burdmann EA, Mehta RL. Acute kidney injury: global health alert. Transplantation 2013; 95: 653-7.

2. Xu X, Nie S, Liu Z, Chen C, Xu G, Zha Y, et al. Epidemiology and Clinical Correlates of AKI in Chinese Hospitalized Adults. Clin J Am Soc Nephrol 2015; 10: 1510-8.

3. Malhotra R, Kashani KB, Macedo E, Kim J, Bouchard J, Wynn S, et al. A risk prediction score for acute kidney injury in the intensive care unit. Nephrol Dial Transplant 2017; 32: 814-22.

4. Uchino S, Kellum JA, Bellomo R, Doig GS, Morimatsu H, Morgera $S$, et al. Acute renal failure in critically ill patients: a multinational, multicenter study. JAMA 2005; 294: 813-8.

5. Cecconi M, Evans L, Levy M, Rhodes A. Sepsis and septic shock. Lancet 2018; 392: 75-87.

6. Mayeux PR, MacMillan-Crow LA. Pharmacological targets in the renal peritubular microenvironment: implications for therapy for sepsis-induced acute kidney injury. Pharmacol Ther 2012; 134: 139-55.

7. Yende S, Austin S, Rhodes A, Finfer S, Opal S, Thompson T, et al. Long-Term Quality of Life Among Survivors of Severe Sepsis: Analyses of Two International Trials. Crit Care Med 2016; 44: 1461-7.

8. Roberts JA, Choi GY, Joynt GM, Paul SK, Deans R, Peake $S$, et al. SaMpling Antibiotics in Renal Replacement Therapy (SMARRT): an observational pharmacokinetic study in critically ill patients. Bmc Infect Dis 2016; 16: 103.

9. Sood MM, Shafer LA, Ho J, Reslerova M, Martinka G, Keenan $S$, et al. Early reversible acute kidney injury is associated with improved survival in septic shock. J Crit Care 2014; 29: 711-7.

10. Gaieski DF, Edwards JM, Kallan MJ, Carr BG. Benchmarking the incidence and mortality of severe sepsis in the United States. Crit Care Med 2013; 41: 1167-74.

11. Biedermann S, Hellmann H. WD40 and CUL4-based E3 ligases: lubricating all aspects of life. Trends Plant Sci 2011; 16: 38-46.

12. Sarikas A, Hartmann T, Pan ZQ. The cullin protein family. Genome Biol 2011; 12: 220.

13. Hochstrasser M. Lingering mysteries of ubiquitin-chain assembly. Cell 2006; 124: 27-34.

14. Sharma P, Nag A. CUL4A ubiquitin ligase: a promising

\section{Conflict of interest statement} interest.

The authors declare that they have no conflict of

drug target for cancer and other human diseases. Open Biol 2014; 4: 130217.

15. lovine B, lannella ML, Bevilacqua MA. Damage-specific DNA binding protein 1 (DDB1): a protein with a wide range of functions. Int J Biochem Cell Biol 2011; 43: 1664-7.

16. Hung MS, Chen YC, Lin P, Li YC, Hsu CC, Lung JH, et al. Cul4A Modulates Invasion and Metastasis of Lung Cancer Through Regulation of ANXA10. Cancers (Basel) 2019; 11: 618 .

17. Sui X, Zhou H, Zhu L, Wang D, Fan S, Zhao W. CUL4A promotes proliferation and metastasis of colorectal cancer cells by regulating $\mathrm{H} 3 \mathrm{~K} 4$ trimethylation in epithelialmesenchymal transition. Onco Targets Ther 2017; 10: 735-43.

18. Al-Harbi NO, Nadeem A, Ahmad SF, Alanazi MM, Aldossari AA, Alasmari F. Amelioration of sepsis-induced acute kidney injury through inhibition of inflammatory cytokines and oxidative stress in dendritic cells and neutrophils respectively in mice: Role of spleen tyrosine kinase signaling. Biochimie 2019; 158: 102-10.

19. Al-Harbi NO, Nadeem A, Ahmad SF, Alotaibi MR, AlAsmari AF, Alanazi WA, et al. Short chain fatty acid, acetate ameliorates sepsis-induced acute kidney injury by inhibition of NADPH oxidase signaling in T cells. Int Immunopharmacol 2018; 58: 24-31.

20. Xia S, Lin H, Liu H, Lu Z, Wang H, Fan S, et al. Honokiol Attenuates Sepsis-Associated Acute Kidney Injury via the Inhibition of Oxidative Stress and Inflammation. Inflammation 2019; 42: 826-34.

21. Kockara A, Kayatas M. Renal cell apoptosis and new treatment options in sepsis-induced acute kidney injury. Ren Fail 2013; 35: 291-4.

22. Mukhopadhyay P, Eid N, Abdelmegeed MA, Sen A. Interplay of Oxidative Stress, Inflammation, and Autophagy: Their Role in Tissue Injury of the Heart, Liver, and Kidney. Oxid Med Cell Longev 2018; 2018: 2090813.

23. Chen $Y$, Jin S, Teng X, Hu Z, Zhang Z, Qiu X, et al. Hydrogen Sulfide Attenuates LPS-Induced Acute Kidney Injury by Inhibiting Inflammation and Oxidative Stress. Oxid Med Cell Longev 2018; 2018: 6717212.

24. Khajevand-Khazaei MR, Mohseni-Moghaddam $P$, Hosseini M, Gholami L, Baluchnejadmojarad T, Roghani $M$. Rutin, a quercetin glycoside, alleviates acute endotoxemic kidney injury in C57BL/6 mice via suppression of 
inflammation and up-regulation of antioxidants and SIRT1. Eur J Pharmacol 2018; 833: 307-13.

25. Ansari MA, Raish M, Ahmad A, Alkharfy KM, Ahmad SF, Attia SM, et al. Sinapic acid ameliorate cadmiuminduced nephrotoxicity: In vivo possible involvement of oxidative stress, apoptosis, and inflammation via NFkappaB downregulation. Environ Toxicol Pharmacol 2017; 51: 100-7.
26. Yuan H, Du S, Deng $Y, X u$ X, Zhang Q, Wang $M$, et al. Effects of microRNA-208a on inflammation and oxidative stress in ketamine-induced cardiotoxicity through Notch/NF-kappaB signal pathways by CHD9. Biosci Rep 2019; 39:BSR20182381.

Received: July 13, 2021

Accepted: July 29, 2021 